\title{
Original Research \\ Evaluating the Impact of Neogene Sediments on River Runoff Formation
}

\author{
Andrius Litvinaitis ${ }^{1 *}$, Lina Bagdžiūnaitè-Litvinaitienè ${ }^{1}$, Valentinas Šaulys ${ }^{1}$, \\ Oksana Barvidiené ${ }^{1}$, Rasa Stankevičiené ${ }^{1}$, Algimantas Česnulevičius ${ }^{2}$ \\ ${ }^{1}$ Department of Water Engineering, Vilnius Gediminas Technical University, Sauletekio av. 11, Vilnius, Lithuania \\ ${ }^{2}$ Centre for Cartography, Vilnius University, Ciurlionio 21/27, Vilnius, Lithuania \\ Received: 14 September 2014 \\ Accepted: 15 March 2015
}

\begin{abstract}
Due to the recently increasing frequency of extreme changes in river runoff regime, scientific literature has dealt with the characteristics of runoff formation. Studies have been carried out on analyzing climate change and a lot of attention has fallen on land-use structures. Migration of precipitation through the river basin is influenced by the lithological composition of sediments. Its structure is determined by analyzing geological and geomorphological maps and by drilling boreholes in the selected area. With the help of boreholes the level of groundwater and lithological composition of sediments can be assessed. An installed system of lysimeters and piezometers in the borehole allows us to monitor the change of groundwater level and the amount of water moving through the unsaturated zone of sediments over time. The set of lysimeter boreholes allows us to capture and map the spacial change of these parameters. Following thorough analysis of the lithological structure of river basins in separate costal zones, this article aims at evaluating river runoff formation characteristics. The basin lithological factor was calculated based on large-scale maps using ArcGis software. In order to carry out more thorough analysis of the influence of lithology in given territories, sections of 0-50 m, 50-200 m, 200-500 m, 500-800 m, 800-1000 m, and >1000 m were established, calculating the distance in meters from the riverbank. Eight river basins of typical lithological structure (sandy, loamy, argillaceous) were selected and examined. The period of the year 1960-2013 was analyzed as this period and the relationship between the runoff and precipitation with correlation of $0.72-0.83$ was established, as well as that with the lithological structure, established following the derivation of a hydromodule.
\end{abstract}

Keywords: neogene sediments, river runoff, basin, precipitation

\section{Introduction}

The distribution of river runoff throughout the year is determined by climatic and bedrock surface factors. Climate influences the overall moisture during the year and runoff regime phase periods. Bedrock surface (the size of a river basin, its lithological composition, and forest area in the river basin) might cause fundamental changes to the runoff regime formed by climatic factors [1-3].

*e-mail: andrius.litvinaitis@vgtu.lt
Recently, cases of ill-timed floods throughout the world have come to the news more and more frequently. It has been estimated that the amount and intensity of precipitation has grown 10 times during the second half of the $20^{\text {th }}$ century [4-6].

In the context of global climate change, climatologists have not yet recorded fundamental changes in multi-annual precipitation patterns but have established its clear seasonal distribution, i.e. winter precipitation has increased significantly while that of summer has seen a significant decrease [7-11]. 
A number of researchers have engaged in the analysis of runoff formation conditions, particularly while analyzing the impact of land-use structures on river runoff [12-15]. H. Pauliukevicius [16] looked into the impact of land use on small river basins runoff. The research has demonstrated a slight and moderate inverse correlation of average annual runoff module with forest area and direct correlation with arable land area in small river basins with varied land use at the end of a low-moisture period and the beginning of a higher moisture period.

However, the amount of scientific research focusing on the aspects of runoff formation in terms of lithological structure of a river basin is scarce; moreover, the existing ones deal with it in terms of water quality since infiltration characteristics of lithological structures determine the quality of both runoff and water [17-20].

Following thorough analysis of the lithological structure of river basins, this article aims at evaluating river runoff formation characteristics.

\section{Materials and Methods}

Eight river basins of typical lithological structure were selected throughout the territory of Lithuania, where longterm water measurements take place, namely sandy ones including the rivers Ula, Mituva, and Zeimena; argillaceous ones including the rivers Verkne and Sesuvis; and loamy ones including the rivers Nevezis, Levuo, and AkmenaDane (Fig. 1). The lithological factor of the basins was calculated based on large-scale quaternary and Lithuanian river maps M 1:10,000 using ArcGis software. Four classes were identified according to soil composition:
1) sand

2) loam-sandy loam (further on referred to as loam)

3) clay

4) swamps and peatbogs.

Infiltration indices were computed for the purpose of further analysis. Lithological analysis of selected parts of river basins was carried out and, where it was possible and long-term water measurement station data was available, "clearest" territories in terms of analysis were identified. In order to carry out more thorough analysis of the influence of lithology in given territories, sections along the riverbed of 0-50 m, 50-200 m, 200-500 m, 500-800 m, 800-1000 m, and $>1000 \mathrm{~m}$ were identified, calculating the distance in meters from the riverbank. Each sections' lithological structure was established.

Quantitative assessment of groundwater in river basins is based on the evaluation of several environmental components (the structure of precipitation, evaporation, runoff, surface split, sediments, and land use). Empirical formulas that describe the quantitative values of these components are used for assessment. In order to assess the infiltration speed, formulas for different intensity precipitation are used [21].

To evaluate the influence of the river runoff of sediment, a water balance equation [22] was used:

$$
R=\sum_{i=1}^{f}\left[\left(K_{f}-E_{f}\right) \cdot A_{f} \cdot\left(\frac{1}{2} \cdot \frac{L_{f}}{v_{f}}+\sum_{i=1}^{f+1} \frac{L_{f+1}}{v_{f+1}}\right)\right]
$$

...where $R$ - runoff depth, (mm); $f$ - section along the riverbed, starting from the farthest from the river; $K_{f}-$ pre-

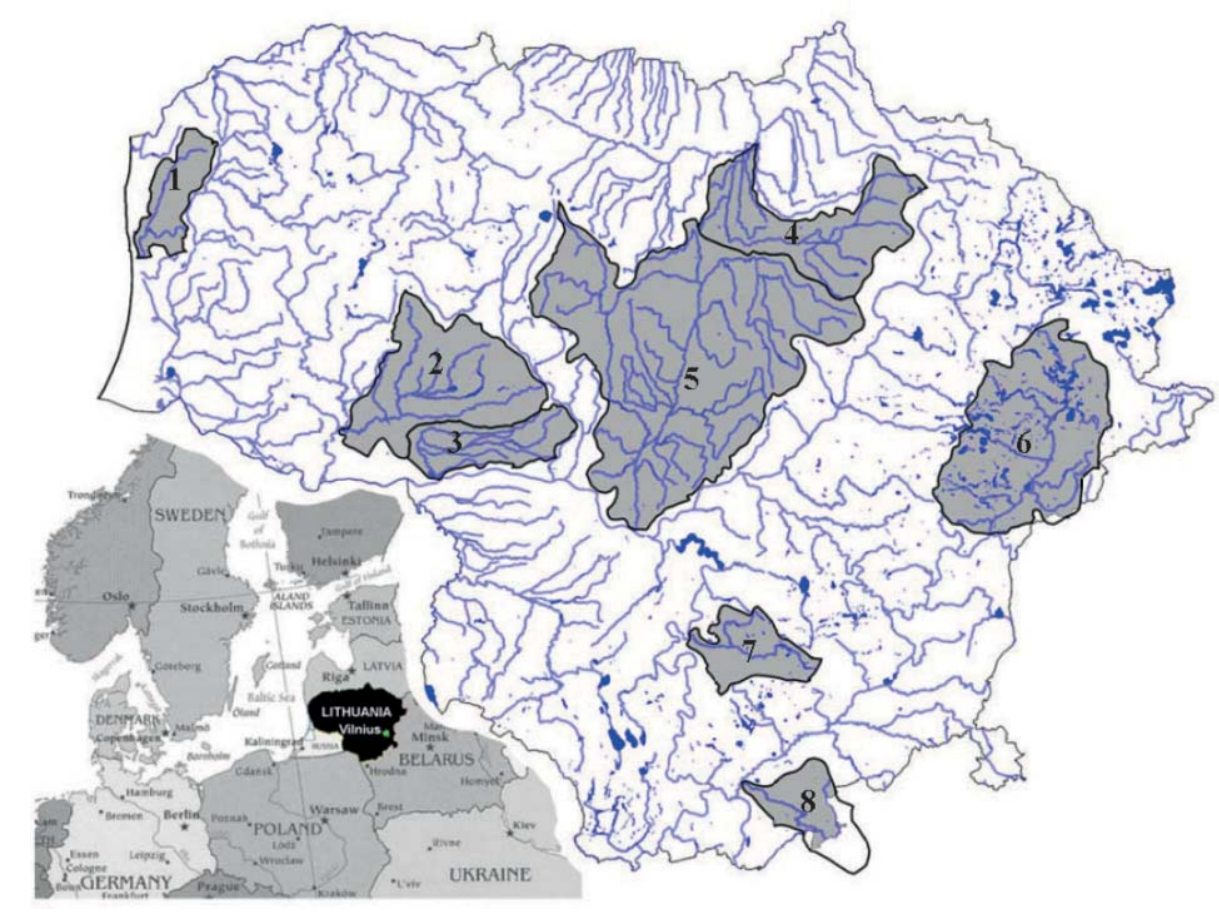

Fig. 1. Analyzed river basins within the territory of Lithuania - 1) Akmena-Dane, 2) Sesuvis, 3) Mituva, 4) Levuo, 5) Nevezis, 6) Zeimena, 7) Verkne, and 8) Ula basins. 
cipitation falling on the section, (mm/d); $E_{f}$ - evaporation from the section, (mm/d); $A_{f}-$ area of the section, $\left(\mathrm{km}^{2}\right)$; $L_{f}-$ width of the section, (m); $v_{f}$ - filtration rate of the section, $(\mathrm{m} / \mathrm{d}) ; L_{f+1}-$ width of the section close to the river, (m); and $v_{f+1}-$ filtration rate of the section close to the river, $(\mathrm{m} / \mathrm{d})$.

The Lithuanian Hydrometeorological Service data of runoff and meteorological conditions (precipitation) in 1960-2013 was used. The relationship between runoff and precipitation was established as well as that with the lithological structure, following derivation of a hydromodule.

Water sample analysis shows the momentary state of the hydrogeological conditions at the research point. It should be noted that hydrogeological conditions of the underground hydrosphere vary a lot in space and time, and that the groundwater is a dynamic system. Therefore, a sampling frequency and a distribution of monitoring locations in the researched area should be well analyzed and based on as much accurate and fuller assessment of geological and hydrogeological conditions as possible. By installing a monitoring point these conditions unavoidably are being more or less deformed: the natural structure of the sediments - a separating layer for the hydraulically watery horizons - is being broken, the underground watery horizon is being directly connected with the atmosphere, etc. In addition, certain conditions arise between the sediments and the monitoring point installed in them at the contact area with the wall. Because of these listed circumstances a certain error appears between the actual hydrogeological conditions of the layer and its values measured at the point of observation.

\section{Results and Discussion}

An important factor is regional and local river basin features, the settlement of which is often problematic. The amount of precipitation in river basins is estimated in several aspects: its quantity, duration, intensity, and frequency. Data of the nearest meteorological stations is used for research and is either interpolated or extrapolated. It is quite difficult to assess the quantity of effective precipitation, leading to the actual river basin water resources. For this it is necessary to know the precipitation retention and interception volumes. In addition, the evaluation of evaporation and infiltration in river basins require individual outside research.

An important indicator determining underground water resources is surface sediment infiltration features. Largescale $(1: 10,000)$ lithological and soil maps are suitable for sediment assessment. Precipitation infiltration conditions are determined by the horizontal and vertical river basin surface diffusion. One of the most important surface diffusion indicators that influences precipitation infiltration is a surface slope. Even a slight surface inclination leads to a rapid direct precipitation water run off the slope or its lower infiltration [21].

Calculating the percentage of a sections' area in the analyzed basins revealed that more than $60 \%$ of the basin ter- ritory is covered by sections of 50-200 m and 200-500 m along all rivers, except for the Zeimena and Verkne rivers (sections of 50-200 m, 200-500 m, and 500-800 m, respectively) and the Ulan, where sections of $50-800 \mathrm{~m}$ cover approximately $40 \%$ of the basin territory; a section of $>1000 \mathrm{~m}$ covers over $35 \%$ of territory. This distribution of section areas is directly influenced by the density of the hydrographic net [23]. This structure was considered in further calculations.

The results of analysis of sediments of sections is seen in Table 1.

The analyzed parts of the Ula and Mituva basins covers the upper and middle reaches of the rivers. The sand covers $69.4 \%$ of the Ula basin area and changes gradually from $52.6 \%$ to $73.9 \%$ across sections. A part of the Mituva basin is covered by sand in $60.0 \%$ of the area, with a rather equal distribution (57.7-63.5\%) in the sections of $0-1000$ $\mathrm{m}$, and $44.6 \%$ in the rest of the territory, namely a section of $>1000 \mathrm{~m}$. This basin structure, considering infiltration characteristics of wet clay, is likely to influence rapid change of runoff in terms of precipitation. Particularly small swamp and peatbog areas, covering only $0.5 \%$ in the sections of $0-1000 \mathrm{~m}$, make $8.0 \%$ of territory in a section of $>1000 \mathrm{~m}$.

The analyzed territory of the Zeimena basin covers the river's middle reaches with a larger area of sand covering $60.2 \%$ of territory, reaching over $66 \%$ in the sections of 800 $>1000 \mathrm{~m}$. The percentage of loam is smaller (18.6-26.9\%) with small amounts of clay (Fig. 2). According to a number of authors, areas with $7 \%$ of territory covered by lakes and $15.3 \%$ covered by swamps and peatbogs influence equal distribution of moisture [3, 23]. Lithological structures are equally distributed across the basin, and only areas of loam and clay may be considered more significant in four territories in the upper and lower reaches. Swamps and peat are distributed in the sections of 0-200 $\mathrm{m}(24.5-32.2 \%)$, with the approximate percentage of $9 \%$ in further sections.

The examined part of the Verkne basin is distinctive for its relatively low sandiness $(26.8-30.9 \%$ in the sections of $0-500 \mathrm{~m}$ ) and loam structures (33.9-41.2\% in the sections of $0-500 \mathrm{~m}$ ) as well as seemingly low percentage of clay, namely $19.3 \%$ of the basin in the sections of $0-500 \mathrm{~m}$ with $93 \%$ of it located in one large holding in the lower reaches of the river. The analyzed part of the Sesuvis basin is characterized by high sandiness in the sections of 1000->1000 m (49.2$75.1 \%)$ and a large amount (32.5-34.7\%) of loam in the sections of $500-1000 \mathrm{~m}$. Closer to the bank, relatively large areas of clay are located in the sections of 0-500 m, covering $28.5-31.0 \%$ and particularly in the middle reaches at $48.9 \%$.

The analyzed area of the Nevezis basin is $68.9 \%$ covered by loam, making $74.7 \%$ in the section of $200-800 \mathrm{~m}$ and $49.9-69.1 \%$ in other sections. Swamps and peatbogs cover $8.5 \%$ of the territory with a larger part (10.4-12.7\%) found along the rivers (in the sections of $0-200 \mathrm{~m}$ and $>1000 \mathrm{~m}$ ), making $4.0-5.9 \%$ in the sections of $200-1000 \mathrm{~m}$.

The upper reaches of Levuo River loam takes $68.2 \%$ of the territory, covering a larger part of the area in all sections and reaching $73.3-77.8 \%$ in the $200-800 \mathrm{~m}$ section. Attention should be drawn to swamps in the section of $>1000 \mathrm{~m}$, where they make $41.9 \%$ (Fig. 2). 
Table 1. Lithological structures of the analyzed river basin parts.

\begin{tabular}{|c|c|c|c|c|c|c|}
\hline \multirow{2}{*}{$\begin{array}{l}\text { Lithological } \\
\text { group }\end{array}$} & \multirow{2}{*}{$\begin{array}{c}\text { River. } \\
\text { Overall, analyzed area } \\
\text { of basin, }\left(\mathrm{km}^{2}\right)\end{array}$} & \multirow[b]{2}{*}{ Section } & \multicolumn{4}{|c|}{ Lithological structure, (\%) } \\
\hline & & & Sand & Loam & Clay & $\begin{array}{c}\text { Swamps and } \\
\text { peatbogs }\end{array}$ \\
\hline \multirow{21}{*}{ Sandy } & \multirow{7}{*}{$\begin{array}{l}\text { Ula. } \\
453.1,379.2\end{array}$} & All & 69.4 & 17.3 & 0.8 & 12.5 \\
\hline & & $0-50 \mathrm{~m}$ & 52.6 & 13.8 & 0.0 & 33.6 \\
\hline & & $50-200 \mathrm{~m}$ & 58.0 & 17.1 & 0.0 & 24.9 \\
\hline & & $200-500 \mathrm{~m}$ & 69.0 & 21.3 & 0.0 & 9.7 \\
\hline & & $500-800 \mathrm{~m}$ & 73.2 & 18.9 & 0.0 & 7.9 \\
\hline & & $800-1000 \mathrm{~m}$ & 71.0 & 19.3 & 0.0 & 9.7 \\
\hline & & over $1000 \mathrm{~m}$ & 73.9 & 14.3 & 2.3 & 9.5 \\
\hline & \multirow{7}{*}{$\begin{array}{c}\text { Mituva. } \\
773.4,403.6\end{array}$} & All & 60.0 & 22.8 & 16.9 & 0.3 \\
\hline & & $0-50 \mathrm{~m}$ & 63.2 & 19.9 & 16.4 & 0.5 \\
\hline & & $50-200 \mathrm{~m}$ & 59.9 & 22.6 & 17.3 & 0.2 \\
\hline & & $200-500 \mathrm{~m}$ & 57.7 & 24.2 & 18.1 & 0.0 \\
\hline & & $500-800 \mathrm{~m}$ & 63.5 & 19.7 & 16.6 & 0.2 \\
\hline & & $800-1000 \mathrm{~m}$ & 60.2 & 35.7 & 3.9 & 0.2 \\
\hline & & over $1000 \mathrm{~m}$ & 44.6 & 45.9 & 1.5 & 8.0 \\
\hline & \multirow{7}{*}{$\begin{array}{c}\text { Zeimena. } \\
2792.7,1828.8\end{array}$} & All & 60.2 & 23.8 & 0.7 & 15.3 \\
\hline & & $0-50 \mathrm{~m}$ & 48.2 & 18.6 & 1.0 & 32.2 \\
\hline & & $50-200 \mathrm{~m}$ & 52.1 & 22.4 & 1.0 & 24.5 \\
\hline & & $200-500 \mathrm{~m}$ & 59.9 & 26.9 & 0.8 & 12.4 \\
\hline & & $500-800 \mathrm{~m}$ & 64.2 & 25.5 & 0.4 & 9.9 \\
\hline & & $800-1000 \mathrm{~m}$ & 66.2 & 23.0 & 0.3 & 10.5 \\
\hline & & over $1000 \mathrm{~m}$ & 66.2 & 20.3 & 0.6 & 12.9 \\
\hline \multirow{14}{*}{ Argillaceous } & \multirow{7}{*}{$\begin{array}{c}\text { Verkne. } \\
727.5,694.1\end{array}$} & All & 33.9 & 39.3 & 19.3 & 7.5 \\
\hline & & $0-50 \mathrm{~m}$ & 26.8 & 33.9 & 19.9 & 19.4 \\
\hline & & $50-200 \mathrm{~m}$ & 29.5 & 36.8 & 21.8 & 11.9 \\
\hline & & $200-500 \mathrm{~m}$ & 30.9 & 41.2 & 23.7 & 4.2 \\
\hline & & $500-800 \mathrm{~m}$ & 38.3 & 41.9 & 15.9 & 3.9 \\
\hline & & $800-1000 \mathrm{~m}$ & 44.5 & 40.4 & 10.5 & 4.6 \\
\hline & & over $1000 \mathrm{~m}$ & 60.2 & 37.2 & 0.0 & 2.6 \\
\hline & \multirow{7}{*}{$\begin{array}{c}\text { Sesuvis. } \\
1915.7,1880.5\end{array}$} & All & 38.9 & 29.9 & 27.2 & 4.0 \\
\hline & & $0-50 \mathrm{~m}$ & 41.2 & 23.4 & 28.5 & 6.9 \\
\hline & & $50-200 \mathrm{~m}$ & 35.7 & 28.2 & 31.0 & 5.1 \\
\hline & & $200-500 \mathrm{~m}$ & 34.1 & 33.2 & 30.4 & 2.3 \\
\hline & & $500-800 \mathrm{~m}$ & 40.9 & 34.7 & 21.6 & 2.8 \\
\hline & & $800-1000 \mathrm{~m}$ & 49.2 & 32.5 & 13.4 & 4.9 \\
\hline & & over $1000 \mathrm{~m}$ & 75.1 & 16.2 & 4.0 & 4.7 \\
\hline \multirow{7}{*}{$\begin{array}{l}\text { Loam-sandy } \\
\text { loam }\end{array}$} & \multirow{7}{*}{$\begin{array}{c}\text { Levuo. } \\
1628.8,523.3\end{array}$} & All & 13.5 & 68.2 & 4.0 & 14.3 \\
\hline & & $0-50 \mathrm{~m}$ & 21.2 & 53.9 & 4.4 & 20.5 \\
\hline & & $50-200 \mathrm{~m}$ & 15.5 & 63.4 & 4.9 & 16.2 \\
\hline & & $200-500 \mathrm{~m}$ & 9.7 & 77.8 & 3.3 & 9.2 \\
\hline & & $500-800 \mathrm{~m}$ & 10.6 & 73.3 & 3.0 & 13.1 \\
\hline & & $800-1000 \mathrm{~m}$ & 15.6 & 61.3 & 2.7 & 20.4 \\
\hline & & over $1000 \mathrm{~m}$ & 15.6 & 39.6 & 2.9 & 41.9 \\
\hline
\end{tabular}


Table 1. Continued.

\begin{tabular}{|c|c|c|c|c|c|c|}
\hline \multirow{2}{*}{$\begin{array}{l}\text { Lithological } \\
\text { group }\end{array}$} & \multirow{2}{*}{$\begin{array}{c}\text { River. } \\
\text { Overall, analyzed } \\
\text { area of basin, }\left(\mathrm{km}^{2}\right)\end{array}$} & \multirow[b]{2}{*}{ Section } & \multicolumn{4}{|c|}{ Lithological structure, (\%) } \\
\hline & & & Sand & Loam & Clay & $\begin{array}{c}\text { Swamps and } \\
\text { peatbogs }\end{array}$ \\
\hline \multirow{14}{*}{$\begin{array}{l}\text { Loam-sandy } \\
\text { loam }\end{array}$} & \multirow{7}{*}{$\begin{array}{c}\text { Akmena-Dane. } \\
580.2,192.2\end{array}$} & All & 5.7 & 90.0 & 4.0 & 0.3 \\
\hline & & $0-50 \mathrm{~m}$ & 7.7 & 82.7 & 4.1 & 5.5 \\
\hline & & $50-200 \mathrm{~m}$ & 5.4 & 87.3 & 3.8 & 3.5 \\
\hline & & $200-500 \mathrm{~m}$ & 4.1 & 90.8 & 4.1 & 1.0 \\
\hline & & $500-800 \mathrm{~m}$ & 7.4 & 86.5 & 3.3 & 2.8 \\
\hline & & $800-1000 \mathrm{~m}$ & 6.1 & 84.5 & 0.2 & 9.2 \\
\hline & & over $1000 \mathrm{~m}$ & 0.0 & 57.8 & 42.2 & 0.0 \\
\hline & \multirow{7}{*}{$\begin{array}{c}\text { Nevezis. } \\
6140.5,4400.9\end{array}$} & All & 21.7 & 68.9 & 0.9 & 8.5 \\
\hline & & $0-50 \mathrm{~m}$ & 26.9 & 59.6 & 0.8 & 12.7 \\
\hline & & $50-200 \mathrm{~m}$ & 22.2 & 66.5 & 0.9 & 10.4 \\
\hline & & $200-500 \mathrm{~m}$ & 18.5 & 74.7 & 0.9 & 5.9 \\
\hline & & $500-800 \mathrm{~m}$ & 19.0 & 74.4 & 0.9 & 5.7 \\
\hline & & $800-1000 \mathrm{~m}$ & 26.0 & 69.1 & 0.9 & 4.0 \\
\hline & & over $1000 \mathrm{~m}$ & 39.7 & 49.9 & 1.0 & 9.4 \\
\hline
\end{tabular}

a)

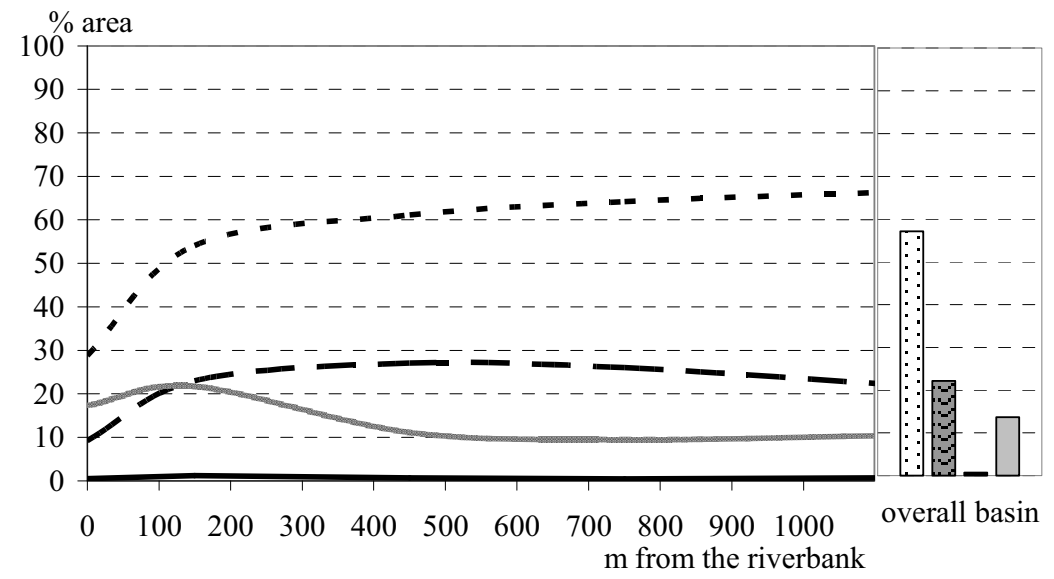

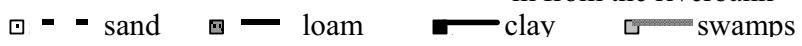

b)

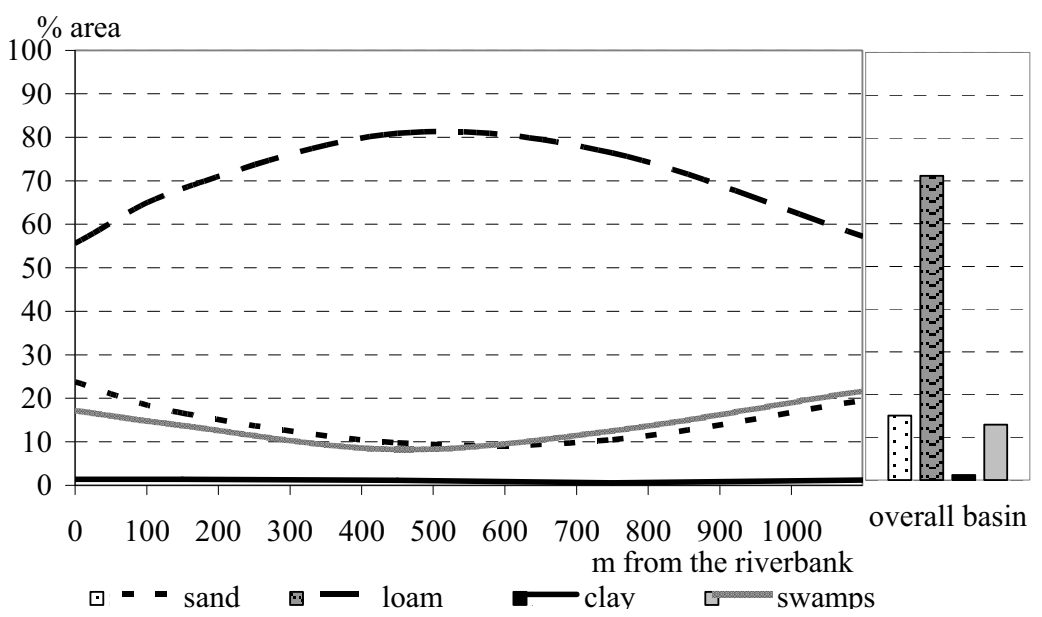

Fig. 2. Change of lithological formations of the rivers with: a) sandy lithology — Zeimena; b) loamy lithology — Levuo, distance from the bank. 
The part of the river Akmena-Dane basin that was selected for examination is covered by $90.0 \%$ loam. The greatest percentage of loam $(82.7-90.8 \%)$ is found in the sections of $0-1000 \mathrm{~m}$.

The analysis of rivers with sand making approximately $60 \%$ of their basins showed that in the case of average annual level of precipitation of $1.45 \%$ probability, the probability of Ula runoff reaches $30.37 \%$, that of the Zeimena reaches $51.03 \%$, and that of the Mituva reaches $9.71 \%$ (Fig. 3). This variation in runoff distribution was determined by other lithological structure elements and, most importantly, their distribution in separate sections. The greatest influence in the Ula and Zeimena basins was caused by swamp areas taking $12.5 \%$ and $15.3 \%$ of the overall basin area, respectively, and as it is widely known, swamps are a good water reservoir. The Mituva basin is distinctive for abundant areas of both sand and clay, particularly in the middle reaches. The analysis of the influence of the amount of precipitation on runoff in separate seasons led to the conclusion that in the case of maximum precipitation $(1.45 \%$ probability) in the Ula, the runoff in spring was $44.83 \%$, in summer it was $20.04 \%$, and in autumn it was $34.50 \%$ probability. Since the river basin contains a large number of swamps and almost no clay areas (they make $0.8 \%$ of the basin, and all are located in the furthest section, in the south of the middle reaches), precipitation has no significant influence on river runoff. The situation in the Zeimena is rather different. Here, in the case of high levels of precipitation, the river runoff probability in spring was $30.37 \%$, in summer it was $32.44 \%$, and in autumn it was $51.03 \%$. The river, similarly to the Ula, contains large sandy areas and a rather significant swamp area (15.3\% of the basin). Moreover, the Zeimena basin includes approximately $0.7 \%$ clay areas located in four holdings. Mituva runoff in different seasons in the case of maximum level of precipitation has been identified as follows: in spring it was 7.64\%, in summer it was $5.58 \%$, and in autumn it was $3.51 \%$. This river presents rather significant differences from the previously analyzed sandy ones like the Mituva basin contains, next to sandy holdings, numerous clay areas that make $16.9 \%$ of the basin and are distributed mainly in the lower reaches. Correlation coefficient was 0.83 (reliability 0.02 ) calculated between precipitation and runoff depth. Therefore, it has been established that in rainy periods with high amounts of precipitation, close-grained lithological structures are capable of preventing infiltration, which results in the water reaching the river channel through surface flow, thus increasing river runoff.

Analyzing rivers with basins where loam areas make over $70 \%$, it has been noticed that in the case of an average level of precipitation probability of $1.45 \%$, which constituted the maximum amount of precipitation in the analyzed period, runoff in the Akmena-Dane corresponded to $11.78 \%$, that of the Levuo corresponded to $32.44 \%$, and

a)

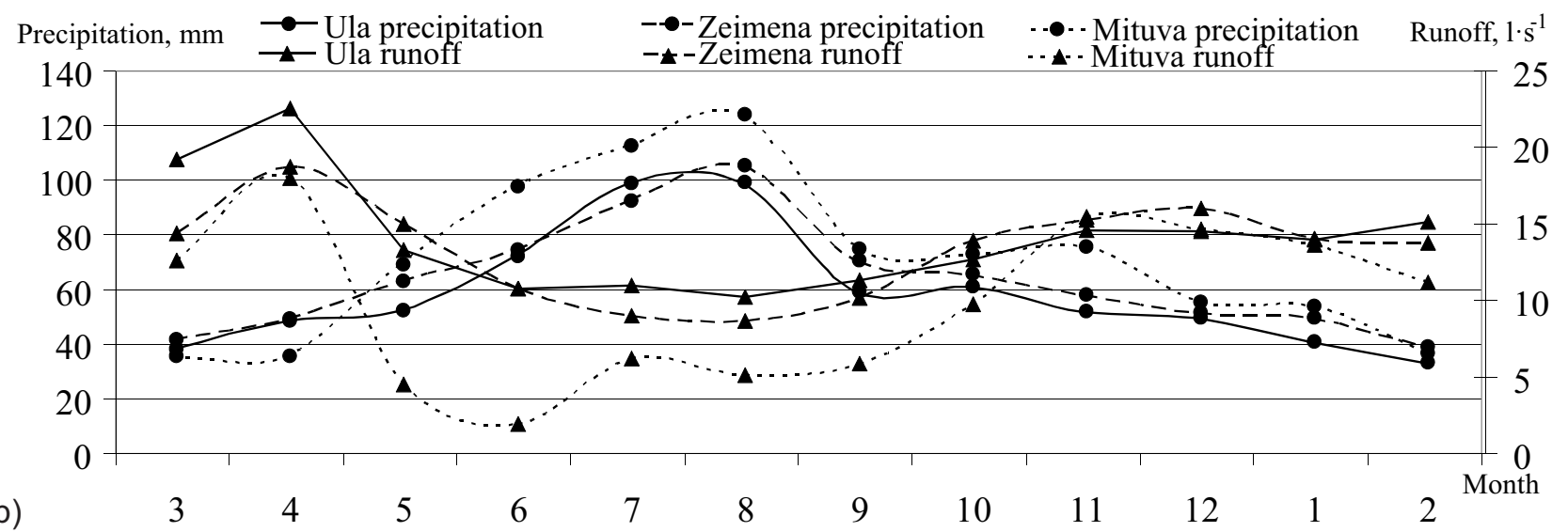

b)

Precipitation, mm $\longrightarrow$ Panevezys precipitation

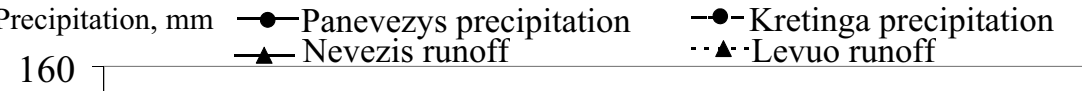

- $\star$ - Akmena-Dane runoff Runoff $1 \cdot \mathrm{s}^{-1}$

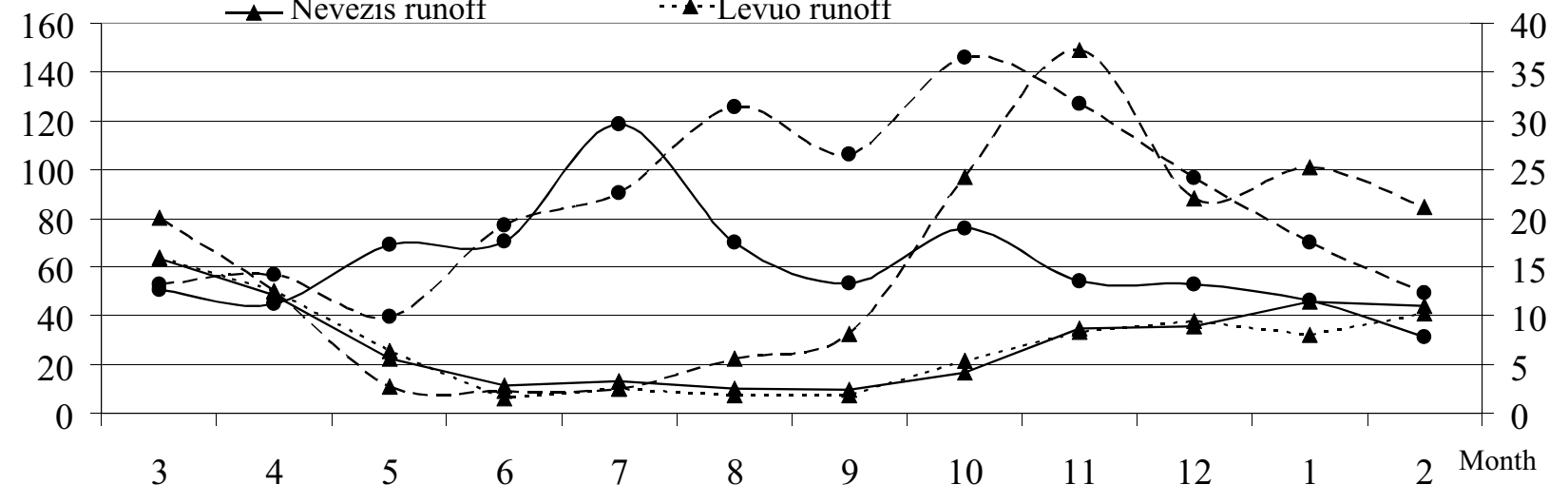

Fig. 3. Distribution of runoff and precipitation in the group of rivers with: a) sandy lithology; b) loamy lithology; period of $1960-2013$. 
that of the Nevezis corresponded to those of $26.24 \%$ probability. Seasonal analysis suggested that runoff in the Akmena-Dane, in the case of maximum precipitation, in spring met $28.31 \%$ of probability, in summer it met $11.78 \%$ of probability, and in autumn $22.11 \%$. A similar situation is observed in the Nevezis and Levuo rivers, but in the latter one the probability of established runoff showed that the runoff is smaller than that in the Nevezis. In the case of maximum level of precipitation, runoff probability in the Levuo and Nevezis rivers changed respectively as follows: $40.70 \%$ and $32.44 \%$ in spring, $53.10 \%$ and $46.90 \%$ in summer, and $13.84 \%$ and $11.78 \%$ in autumn. This difference might arise due to the fact that swamps make $14.3 \%$ of the overall area of the river Levuo basin; moreover, they are more equally distributed throughout all sections. Bigger amounts of loam have greater influence on seasonal runoff, which was revealed while analyzing the change of Akmena-Dane runoff throughout the year. Correlation coefficient calculated between precipitation and runoff depth was 0.75 (reliability 0.03 ).

The analysis of the change of runoff in the Sesuvis suggested that in the case of maximum level of precipitation river runoff was $5.58 \%$, while in the Verkne it was $11.78 \%$ of probability. Seasonal analysis showed that in spring the runoff probability in the Sesuvis was $22.11 \%$ and in the Verkne it was $38.64 \%$. In summer the runoffs changed respectively to $5.58 \%$ and $24.17 \%$, and in autumn they were $3.51 \%$ and $17.98 \%$ of probability. The runoff probability of the Sesuvis is influenced by clay areas mainly distributed in the middle reaches and covering up to $30 \%$ of the section area. In the Verkne basin the correlation of precipitation and runoff is reduced by the presence of swamp areas making $7.5 \%$ and those of loam making up to $35 \%$ of the basin. The situation of the river resembles that of the Mituva as the areas of all lithological structures in their basins are similar. Correlation coefficient was 0.72 (reliability 0.02 ), calculated between precipitation and runoff depth.

\section{Conclusions}

In the analyzed basins of rivers attributed to the group of rivers with sandy lithology (over $60 \%$ of sand), sand areas in the sections increase moving to the direction opposite the river bank from $44.6 \%$ to $75.7 \%$ of section area; loam areas are the largest in the sections of 200-800 m (18.9-26.9\%); clay areas are distributed unequally. Sand areas of over $50 \%$ in the basins, separate parts of a basin, or sections have inversely proportionate influence on river runoff.

The most intensive infiltration of precipitation takes place in the basins with dominant sandy sediment. Generally the sandy sediment infiltration coefficient concluded to $6.2 \mathrm{~m} /$ day.

The direct surface runoff and low infiltration conditions were mainly determined in the river basins of loamy sediment. Infiltration coefficient of loamy sediment reached 1.3 $\mathrm{m} /$ day.
The changes of direct surface runoff and infiltration conditions were mainly predetermined by the changes of land use structure in the investigated river basins and especially by the expansion of urbanized areas.

It has been established that larger (over $12 \mathrm{~km}^{2}$ ) homogenous argillaceous areas have double impact on runoff: direct in periods with precipitation probability of $11.78-55.17 \%$ and inversely proportionate in period with precipitation probability of $69.63-98.55 \%$. In river basins of the loamy group of rivers, loam areas make $68.2-90.0 \%$ of the basin area with largest loam areas registered in the sections of 200-500 m. With loam percentage in a river basin, part or section of a basin lower that to $70 \%$, the characteristics of correlation of precipitation and runoff resemble those of sandy river basins and in the case of those with loam percentage higher than $70 \%$, the relationship between precipitation and runoff resembles that of argillaceous basins. Reliable correlation coefficients of $0.72-0.83$ were calculated between precipitation and runoff depth.

\section{References}

1. ARNELL N. W., GOSLING S. N. The impacts of climate change on river flow regimes at the global scale. J. Hydrol. 486, 351, 2013.

2. GAILIUŠIS B., JABLONSKIS J., KOVALENKOVIENE M. Lithuanian rivers: Hydrography and runoff. Kaunas: LEI. 2001 [In Lithuanian].

3. UHLENBROOK S., MC DONNELL J., LEIBUNDGUT C. Foreword to the special issue: Runoff generation and implications for river basin modelling. Freiburger Schriften zur Hydrologie. 10, (13), 4, 2001.

4. AERTS JEROEN C.J.H., WOUTER BOTZEN W.J. Climate change impacts on pricing long-term flood insurance: A comprehensive study for the Netherlands. Global Environmental Change 21, 1045, 2011.

5. POTTER N.J., CHIEW F.H.S., FROST A.J. An assessment of the severity of recent reductions in rainfall and runoff in the Murray-Darling Basin. J. Hydrol. 381, 52, 2010.

6. PFISTER L., KWADIJK J., MUSY A., BRONSTERT A., HOFFMANN L. Climate change, Land use change and runoff prediction in the Rhine - Meuse basins. River Res. Appl., 20, 229, 2004.

7. VAN STEENBERGEN N., WILLEMS P. Method for testing the accuracy of rainfall-runoff models in predicting peak flow changes due to rainfall changes, in a climate changing context. J. Hydrol. 414-415, 425, 2012.

8. TRENBERTH K. E. Changes in precipitation with climate change. Climate Res. 47, 123, 2011.

9. BUKANTIS A., RIMKUS E. Climate variability and change in Lithuania. Acta Zool-Stockholm 15, (2), 100, 2005.

10. GALVONAITE A., VALIUKAS D. Lithuanian climate change (1991-2003). Vilnius. 80, 2005 [In Lithuanian].

11. BUKANTIS A., GULBINAS Z. The influence of climatic variations on physical geographical processes in Lithuania. Vilnius. 280, 2001 [In Lithuanian].

12. LOPEZ-MORENO J. I., VICENTE-SERRANO S. M., MORAN-TEJEDA E., ZABALZA J., LORENZOLACRUZ J., GARCÍA-RUIZ J. M. Impact of climate evolution and land use changes on water yield in the Ebro basin. Hydrol. Earth Syst. Sci. 15, (1), 311, 2011. 
13. MANGO L. M., MELESSE A. M., MCCLAIN M. E., GANN D., SETEGN S. G. Land use and climate change impacts on the hydrology of the upper Mara River Basin, Kenya: results of a modeling study to support better resource management, Hydrol. Earth Syst. Sci., 15, 2245, 2011.

14. ASHAGRIE A. G., DE LAAT P. J. M., DE WIT M. J. M., TU M., UHLENBROOK S. Detecting the influence of land use changes on Floods in the Meuse River Basin - the predictive power of a ninety-year rainfall-runoff relation. Hydrol. Earth Syst. Sci. Discuss. 3, 529, 2006.

15. ZIELIŃSKI P., GÓRNIAK A., SUCHOWOLEC T. Changes in Water Chemistry Along the Course of Two Rivers with Different Hydrological Regimes. Pol. J. Environ. Stud. 12, (1), 111, 2003.

16. PAULIUKEVICIUS H. Effect of land use on the runoff. Water Management Engineering. 30, (50), 88, 2006.

17. PINIEWSKI M., LAIZE C. L.R., ACREMAN M. C., OKRUSZKO T., SCHNEIDER C. Effect of climate change on environmental flow indicators in the Narew Basin, Poland. J. Environ. Qual., 43, (1), 155, 2014.

18. ŠANDA M., VITVAR T., KULASOVÁ A., JANKOVEC J., CÍSLEROVÁ M. Run-off formation in a humid, temperate headwater catchment using a combined hydrological, hydrochemical and isotopic approach (Jizera Mountains, Czech Republic). Hydrol. Process. 28, 3217, 2013.

19. HILL A. R., VIDON P. G. F., LANGAT J. Denitrification Potential in Relation to Lithology in Five Headwater Riparian Zones. J. Environ. Qual. 33, 911, 2004.

20. DEVITO K. J., FITZGERALD D., HILL A. R., ARAVENA R. Nitrate Dynamics in Relation to Lithology and Hydrologic Flow Path in a River Riparian Zone. J. Environ. Qual. 29, 1075, 2000.

21. CESNULEVICIUS A. Infiltration properties of small river basins in Vilnius and their relationship to relief erosion. Geography. 34, (1), 5, 1998.

22. LITVINAITIS A. The evaluation of the influence of coastal sediments on river water quality: doctoral dissertation: technological sciences, environmental engineering (04T) Vilnius Gediminas Technical University, pp. 143, 2013.

23. JABLONSKIS J., KOVALENKOVIENE M., TOMKEVICIENE A. Channel Network of the Lithuanian Rivers and Small Streams. Lithuanian Energy Institute. Annales Geographicae 40, (1), 46, 2007. 